\title{
A sensitive and specific in vitro bioassay for activin using a mouse plasmacytoma cell line, MPC-11
}

\author{
D J Phillips, J N Brauman, A J Mason ${ }^{1}$, D M de Kretser and \\ M P Hedger \\ Institute of Reproduction and Development, Monash University, Clayton, Victoria 3168, Australia \\ ${ }^{1}$ Prince Henry's Institute of Medical Research, Monash Medical Centre, Clayton, Victoria 3168, Australia \\ (Requests for offprints should be addressed to D J Phillips, Institute of Reproduction and Development, Level 3, Block E, Monash Medical Centre, \\ 246 Clayton Road, Clayton, Victoria 3168, Australia) \\ (A J Mason is now at Biota Molecular Biology Laboratory, Microbiology Department, Monash University, Clayton, Victoria 3168, Australia)
}

\begin{abstract}
A new in vitro bioassay for activin was developed using the mouse plasmacytoma cell line, MPC-11. Human recombinant (hr) activin A dose-dependently inhibited the proliferation of these cells, whereas a range of other factors, including inhibin, follistatin and transforming growth factor- $\beta 1,-\beta 2$ and $-\beta 3$ had no effect. Conditioned medium containing activin $\mathrm{B}$ induced an inhibition similar to hr-activin A. The inhibitory influence of activin A could be blocked by follistatin, but not by hr-inhibin A. This bioassay had a sensitivity for activin A of around $0.4 \mathrm{ng} / \mathrm{ml}$, an $\mathrm{ED}_{50}$ response of $3.5 \mathrm{ng} / \mathrm{ml}$, and an intraassay coefficient of variation of $<11 \%$. It offers substantial advantages over existing in vitro activin bioassays in terms of ease of use, specificity and throughput. The utility of the MPC-11 bioassay was demonstrated in the purification of activin from amniotic fluid, where an almost identical
\end{abstract}

profile of bioactive activin A was detected compared with the pituitary cell bioassay of activin. Bioactive activin could also be detected in unpurified ovine allantoic and amniotic fluids and bovine follicular fluid. Measuring activin in untreated and heat-treated human sera or seminal plasma was hampered by a non-specific inhibitory effect, so that several serum samples did not run parallel with the hr-activin A standard. This inhibitory effect by serum could not be overcome by addition of follistatin, suggesting it is not activin-like bioactivity. This new bioassay for activin demonstrates widespread applicability for monitoring of purified or partially purified samples during purification procedures, bioactivity measurements, receptor-binding studies and assays of cell culture medium. Journal of Endocrinology (1999) 162, 111-116

\section{Introduction}

Activin is a pluripotent growth factor that was originally isolated based on its ability to stimulate follicle-stimulating hormone (FSH), but it is now known to have other important roles during development, erythropoiesis, inflammation and wound healing (DePaolo 1997). In vitro bioassays for activin have been developed using the production of FSH from cultured pituitary cells (Robertson et al. 1992), the accumulation of haemoglobin in K562 erythroleukaemia cells (Schwall \& Lai 1991), and the ability to induce mesoderm tissue in animal cap explants of Xenopus (de Winter et al. 1992). These assays normally are responsive to both activin $\mathrm{A}$ and activin $\mathrm{B}$, which are formed from homodimers of inhibin $\beta_{\mathrm{A}}$ and $\beta_{\mathrm{B}}$ subunits respectively; these two subunits share around $64 \%$ sequence homology. While each of these assays has been used to measure bioavailable activin, they have various shortcomings. The pituitary cell assay requires primary cultures of rat pituitary cells, is lengthy and is responsive to other FSH regulators such as inhibin and the activin-binding protein, follistatin. The K562 assay is responsive to many erythroid differentiation factors other than activin, and haemoglobin production must be corrected for cell number. The animal cap assay is semiquantitative and is suitable only for small numbers of samples.

One of the sites of production of activin A is in the bone marrow (Shao et al. 1992, Yamashita et al. 1992, Uchimaru et al. 1995) and recently Brosh et al. (1995) have purified activin A from bone marrow stromal cells. In their screening protocols, the mouse plasmacytoma cell line, MPC-11 (Laskov \& Scharff 1970), was found to be exquisitely sensitive to inhibition by activin A. Moreover, the inhibitory effects on growth in this cell line were not mimicked by a variety of other cytokines and growth factors (Brosh et al. 1995) such as the interleukins, platelet derived growth factor, fibroblast growth factor, interferon 

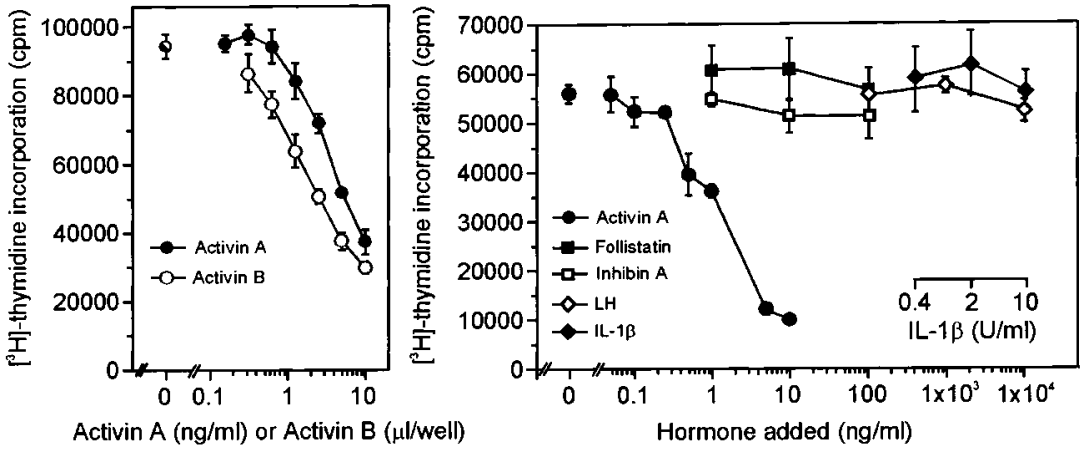

Figure 1 Inhibition of proliferation by MPC-11 cells, measured as thymidine incorporation, in response to increasing doses of hr-activin $\mathrm{A}(\mathrm{ng} / \mathrm{ml})$ or conditioned medium containing activin B (left panel). The right panel depicts the lack of effect of follistatin, hr-inhibin A, LH or interleukin- $1 \beta$. Values are means \pm S.D., $n=4$ replicates.

$\gamma$, colony stimulating factors, leukaemia inhibitory factor and, most importantly, transforming growth factor- $\beta$ (TGF $\beta$ ), which is structurally related to activin.

Given the shortcomings inherent in the existing bioassays for activin, and the promising response of plasmacytoma cells to activin A, we evaluated the MPC-11 cell line as the basis of a new in vitro bioassay for activin. The assay was tested for its measurement of both activin A and $\mathrm{B}$, and in terms of its ease of use, specificity and throughput.

\section{Materials and Methods}

\section{Reagents}

MPC-11 plasmacytoma cells were generously provided by Dr Alan Harris of the Walter and Eliza Hall Institute, Melbourne, Australia. Cells were cultured in Dulbecco's modified Eagle's medium (DMEM; Gibco BRL, Gaithersburg, MD, USA) supplemented with 10\% fetal calf serum (FCS), $24 \mathrm{mM}$ bicarbonate, L-glutamine, non-essential amino acids and Pen-strep (CSL, Melbourne, Australia). Culture flasks and 96-well plates were supplied by Becton Dickinson (Franklin Lakes, NJ, USA). Human recombinant (hr) activin A, hr-inhibin A and bovine follistatin were as described previously (Robertson et al. 1992), activin B was from conditioned medium of 293 cells transfected with an activin $\beta_{\mathrm{B}}$ subunit expression plasmid (Mason et al. 1989), ovine luteinizing hormone (LH) was generously supplied by the National Hormone and Pituitary Program (NHPP, Torrance, CA, USA) and hr-interleukin-1 $\beta$ (IL-1 $\beta$ ), hr-TGF $\beta 1,-\beta 2$ and $-\beta 3$ were purchased from R\&D Systems (Minneapolis, MN, USA). Human sera were obtained from the Melbourne Blood Bank from normal volunteers and pooled serum from women in week 39 of pregnancy was generously provided by Dr Euan Wallace, Department of Obstetrics and Gynaecology, Monash University, with the appropriate ethical approval and informed consent of the patients.

\section{Cell culture procedures}

Cells were cultured in a 95\% air $/ 5 \% \mathrm{CO}_{2}$ atmosphere at $37^{\circ} \mathrm{C}$, and passaged at $1 \times 10^{6}$ cells $/ 25 \mathrm{~cm}^{2}$ flask every second day. For experiments, $100 \mu \mathrm{l}$ cell suspension were added to 96-well plates at a density of 1000 viable cells/well in culture medium containing $25 \mu \mathrm{M}$ $\beta$-mercaptoethanol. Activin, other test reagents and sera $(100 \mu \mathrm{l} /$ well) were added to the cultures diluted in phosphate buffer ( $\mathrm{pH} \mathrm{7.4)} \mathrm{containing} 6.5 \mathrm{mM} \mathrm{Na}_{2} \mathrm{HPO}_{4}$, $1.5 \mathrm{mM} \quad \mathrm{KH}_{2} \mathrm{PO}_{4}, 0.14 \mathrm{M} \mathrm{NaCl}, 0.01 \% \quad \mathrm{BSA}$ and Pen-strep. Cells were cultured in the presence of test reagents for two days; on the third day $25 \mu \mathrm{l}\left[{ }^{3} \mathrm{H}\right]$ thymidine $(0.25 \mu \mathrm{Ci} / 25 \mu \mathrm{l}, 6.7 \mathrm{Ci} / \mathrm{mmol}$; NEN, Wilmington, DA, USA) were added to each well and $24 \mathrm{~h}$ later the cells harvested and thymidine incorporation assessed using standard methodologies (Robertson et al. 1992). All test preparations, including activin standards and sera, were assayed in quadruplicate, and experiments were repeated at least twice. Relative bioactivity and parallelism were assessed using parallel-line bioassay statistics as previously described (Imade et al. 1997).

\section{Results}

Initial experiments evaluated culture conditions, including cell number (50-10 000 cells/well), FCS concentration (0$30 \%)$, presence and concentration of $\beta$-mercaptoethanol $(0-300 \mu \mathrm{M})$, and a range of buffers in which to dilute test samples (data not shown). Optimum responses in terms of proliferation, sensitivity to activin and response range were found with a combination of 1000 cells/well, 10\% FCS, $25 \mu \mathrm{M} \beta$-mercaptoethanol, and test substances diluted 


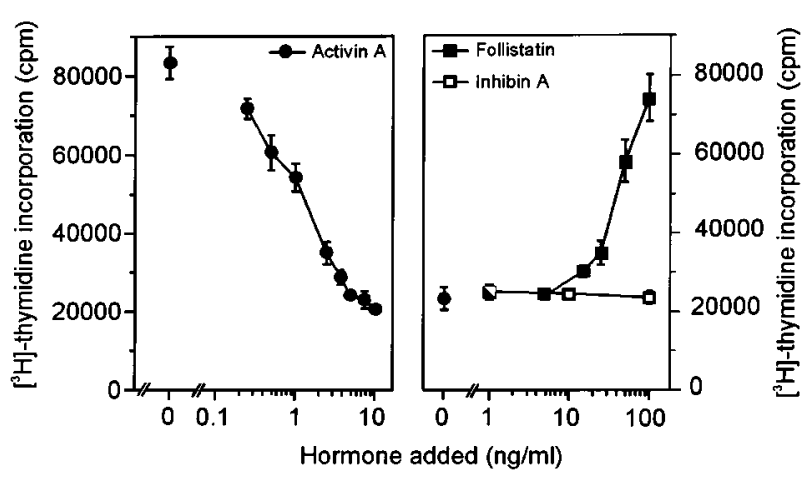

Figure 2 Blocking of the activin-induced inhibition of MPC-11 cells (left panel) by increasing amounts of follistatin added to the cultures in the presence of $5 \mathrm{ng} / \mathrm{ml}$ hr-activin A (right panel). Addition of hr-inhibin A in the presence of $5 \mathrm{ng} / \mathrm{ml} \mathrm{hr}$-activin A had no effect. Values are means \pm S.D., $n=4$ replicates.

in phosphate buffer as described in the Materials and Methods section. These conditions were used in all other experiments.

The inhibitory response of these cells to activin was reproducible and was detectable with concentrations as little as $40 \mathrm{pM}$ (Fig. 1). Proliferation was inhibited by activin A to around $20 \%$ of basal levels, but could not be completely suppressed over the dose range tested. Over 16 assays, the mean sensitivity of response to hr-activin A, defined as $2 \times \mathrm{SD}$ from the 0 standard was $0 \cdot 4 \pm 0 \cdot 3 \mathrm{ng} /$ $\mathrm{ml}$, the $\mathrm{ED}_{50}$ response (50\% of baseline proliferation) was $3.5 \pm 1.7 \mathrm{ng} / \mathrm{ml}$ and the intra-assay coefficient of variation was $10.9 \pm 7 \cdot 7 \%$. The interassay coefficient of variation for an activin-containing preparation was $15 \cdot 7 \%$ ( $n=7$ assays), and the recovery of spiked activin added to an activincontaining biological fluid (ovine amniotic fluid) was $92 \cdot 8 \pm 9 \cdot 5 \%$ (mean \pm s.D.; $n=12$ observations). In each assay, activin was measured over the range of $0 \cdot 16-10 \mathrm{ng} /$ $\mathrm{ml}$, representing a working range of six serial dilutions. In addition, the response of these cells to activin $\mathrm{B}$ appeared to be similar to that of activin A (Fig. 1), consistent with other published bioassays (Mason et al. 1989). Importantly, this bioassay did not detect inhibin A or follistatin even at relatively high concentrations. Furthermore, there was no significant effect on proliferation of hr-TGF $\beta 1,-\beta 2$ or $-\beta 3$ at concentrations of up to $250 \mathrm{ng} / \mathrm{ml}$ (data not shown). Although follistatin alone did not influence proliferation in the MPC-11 bioassay, follistatin blocked the inhibitory influence of activin A (Fig. 2), indicating that these cells respond only to bioavailable activin. In contrast to follistatin, inhibin A did not antagonize activin's effects.

The utility of the MPC-11 assay is demonstrated in Fig. 3, where activin activity isolated from ovine amniotic fluid from a previously published study was detected (de Kretser et al. 1994). Of note is that fractions containing activin diluted in parallel with the hr-activin A standard curve and the profile of activity was almost identical with that detected by the pituitary cell bioassay, but not with the profile of immunoreactive activin. Furthermore, unpurified ovine amniotic and allantoic fluids, and bovine follicular fluid contained measured amounts of activin activity that diluted in parallel with the standard curve (data not shown).

We evaluated the MPC-11 assay for its ability to measure activity in human serum samples. Initial experiments indicated that addition of $>5 \mu$ l human serum caused a non-specific cytotoxic effect where proliferation of the cells was abolished completely (data not shown). This type of phenomenon is common in cells of mouse lymphoid origin and is due to antibody/complementmediated lysis (Pruett \& Lackey 1987). To combat this effect, we performed a series of experiments exploring the efficacy of dialysing and heating human serum. Dialysing (3500 molecular cutoff) of samples did not remove the cytotoxicity, but heating the serum for various periods and temperatures was effective (data not shown). The most effective treatment was found to be the heating of human serum for $30 \mathrm{~min}$ at $56{ }^{\circ} \mathrm{C}$ which abolished the cytotoxic effect without damaging the activity of hr-activin A
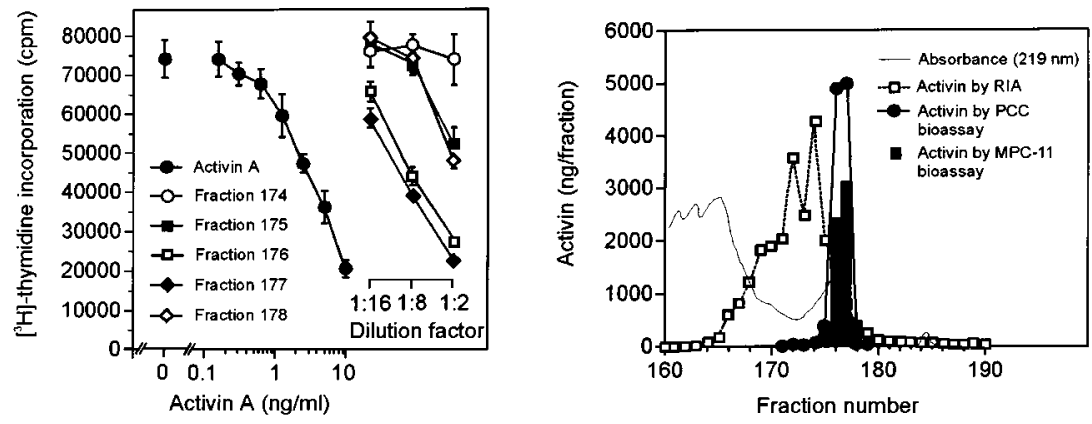

Figure 3 Use of the MPC-11 bioassay to detect activin in the purification of ovine amniotic fluid (de Kretser et al. 1994). The left panel depicts serial dilutions of various fractions that run parallel with the standard curve; values are means \pm S.D. The right panel shows the comparison between activin detected by the MPC-11 bioassay, a pituitary cell (PCC) bioassay and the activin radioimmunoassay. 


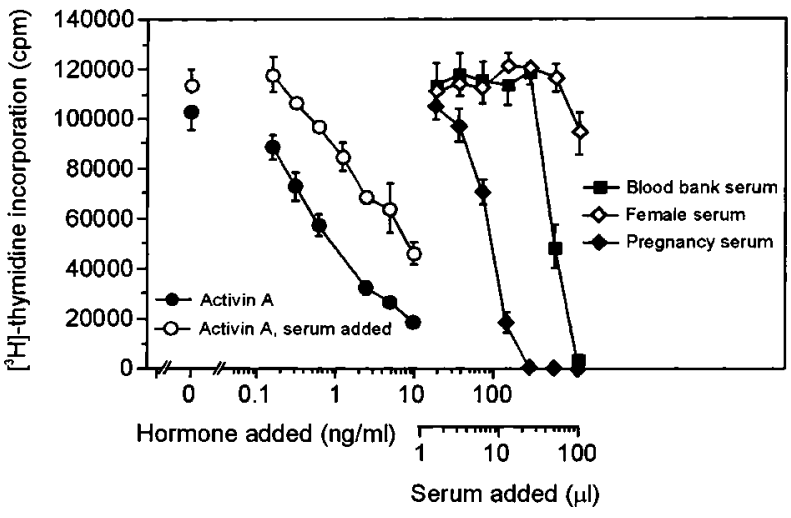

Figure 4 Effects of heat-treated serum in the activin bioassay. Addition of serum $(12.5 \mu \mathrm{l} /$ well $)$ to the standard curve reduced the sensitivity but not the slope. Serial dilutions of pregnancy or blood bank serum did not run parallel with either activin standard curve. Values are means \pm S.D., $n=4$ replicates.

subjected to identical treatment (Fig. 4). Despite the removal of this effect, several serum samples did not dilute in parallel with the activin standard curve, as was the case for a limited number of seminal plasma samples that were assayed. This effect was particularly noticeable in activincontaining serum from late pregnancy, and also in blood bank serum which contained minimal amounts of activin A by RIA (Fig. 4). Other sera, such as non-pregnant female serum and normal male serum appeared to have small amounts of activin-like activity that ran parallel with the standard curve over a limited number of doses. Addition of blood-bank serum to the activin standard reduced the sensitivity of the assay but did not alter the slope of activity (Fig. 4). Furthermore, this non-specific inhibitory effect of serum could not be blocked by the addition of follistatin to the cultures, even at concentrations that neutralized the effect of $5 \mathrm{ng} / \mathrm{ml}$ activin A (data not shown).

\section{Discussion}

In this study we have characterized the response of the MPC-11 cell line to activin and other agents and found that it offers an extremely reproducible, sensitive and convenient in vitro bioassay for activin. With the bioassay format described in the present study, up to 30 samples at three serial dilutions could be measured in one assay with a turn-around of four days. Interestingly, the MPC-11 cells have a similar response to both activin A and B as evidenced by the similar response slopes. The response of the current bioassay to activin B is consistent with other published bioassays for activin (Mason et al. 1989). On this basis we would expect this assay to measure activin $A B$, although recent evidence using an immunoassay for activin $\mathrm{AB}$ suggests that the concentrations of this form are generally low in biological fluids (Evans et al. 1997). Crossreactivity with other forms of activin containing $\beta_{\mathrm{C}}$, $\beta_{\mathrm{D}}$ and $\beta_{\mathrm{E}}$ subunits is likely to be minimal, based on their lower sequence homology compared with the more closely related $\beta_{\mathrm{A}}$ and $\beta_{\mathrm{B}}$ subunits (Hötten et al. 1995, Oda et al. 1995, Fang et al. 1996). However, until these proteins are available in purified form, this premise cannot be formally tested.

Previous studies using this cell line have demonstrated that other growth factors and cytokines, including TGF $\beta$, do not mimic activin's effects on these cells (Brosh et al. 1995). This is in contrast to both the K562 and pituitary cell bioassays, which are influenced by TGF $\beta$ (Ying et al. 1986, Chen et al. 1989, Burger et al. 1994). Furthermore, the pituitary cell bioassay is also responsive to inhibin and follistatin (Robertson et al. 1992), whereas these proteins had no effect when tested in the MPC-11 bioassay. Despite this observation that follistatin alone did not influence proliferation in the MPC-11 bioassay, follistatin blocked the inhibitory influence of activin A, indicating that these cells respond only to bioavailable activin. The molar excess of follistatin required to neutralize activin's activity was several fold more than the calculated theoretical value of 2:1 (Shimonaka et al. 1991). Nevertheless, our findings with the present assay are consistent with the excesses of follistatin required in cultured pituitary cells or K562 cells (Krummen et al. 1993). In contrast to follistatin, inhibin A did not antagonize activin's effects, as it does in pituitary cell and K562 cell cultures (Yu et al. 1987, Robertson et al. 1992). This finding needs to be explored further, particularly in view of the hypothesis that inhibin blocks the binding of activin to its type II receptor (Martens et al. 1997), and the proposed existence of a distinct inhibin receptor (Draper et al. 1998).

To demonstrate the utility of the MPC-11 assay, activin bioactivity was measured in unpurified allantoic, amniotic and follicular fluids, and also in fractions from the purification of activin A derived from ovine amniotic fluid (de Kretser et al. 1994). The absolute amounts of activin detected by the MPC-11 bioassay from these fractions were less than those measured by the pituitary cell bioassay, but this most likely relates to the use of a different hr-activin A standard. Importantly, the profile characteristics were similar between the two bioassay formats, suggesting that the assays have similar characteristics when measuring activin A.

Current activin bioassays are not suitable for detecting activin in serum or plasma samples. We evaluated the MPC-11 assay for its ability to measure activity in human serum samples, but we were unable to overcome a lack of parallelism in some of the human sera tested or in human seminal plasma. Non-specific interference is a problem frequently encountered in biological assays in vitro when dealing with crude biological samples, and particularly growth inhibitory assays. At this time we have no explanation for this phenomenon, but our finding that this effect 
could not be blocked by follistatin strongly suggests that it is not an activin-like activity. Regardless, several recent studies have highlighted the fact that the concentrations of unbound, bioavailable activin are extremely low (Sakamoto et al. 1996, Woodruff et al. 1997, McConnell et al. 1998), well below the sensitivity of the MPC-11 bioassay or other existing bioassays for activin. Therefore, to measure bioactive activin in peripheral sera would require a large improvement in the sensitivity of the assay or an approach involving extraction or purification of activin from serum.

In summary, we have utilized the MPC-11 cell line to develop an in vitro bioassay for activin that has several advantages over existing bioassays. The assay is sensitive, measures both activin $\mathrm{A}$ and $\mathrm{B}$, but does not crossreact with inhibin, follistatin or TGF $\beta 1,-\beta 2$ or $-\beta 3$. Follistatin is able to neutralize the activin activity in the bioassay, indicating that only unbound activin is detected. Activin bioactivity was detected in semi-purified fractions from ovine amniotic fluid, but activin in serum could not be detected due to the masking of a non-specific inhibitory effect. This does not detract from the utility of the bioassay for purified or partially purified samples, which allows several important applications, including monitoring of purification, bioactivity measurements, receptor-binding studies and assays of cell culture medium.

\section{Acknowledgements}

This work was funded by the NH\&MRC of Australia. We thank the NHPP for the provision of hormone preparations, and Julie Muir and Lynda Foulds for excellent research assistance.

\section{References}

Brosh N, Sternberg D, Honigswachs-Sha'anani J, Lee B-C, Shav-Tal Y, Tzehoval E, Shulman LM, Toledo J, Hacham Y, Carmi P, Jiang W, Sasse J, Horn F, Burstein Y \& Zipori D 1995 The plasmacytoma growth inhibitor restrictin-P is an antagonist of interleukin 6 and interleukin 11. Identification as a stroma-derived activin A. Journal of Biological Chemistry 270 29594-29600.

Burger PE, Dowdle EB, Lukey PT \& Wilson EL 1994 Basic fibroblast growth factor antagonizes transforming growth factor $\beta$-mediated erythroid differentiation in K562 cells. Blood 83 1808-1812.

Chen LL, Dean A, Jenkinson T \& Mendelsohn J 1989 Effect of transforming growth factor- $\beta 1$ on proliferation and induction of hemoglobin accumulation in K-562 cells. Blood 74 2368-2375.

DePaolo LV 1997 Inhibins, activins, and follistatins: the saga continues. Proceedings of the Society for Experimental Biology and Medicine 214 328-339.

Draper LB, Matzuk MM, Roberts VJ, Cox E, Weiss J, Mather JP \& Woodruff TK 1998 Identification of an inhibin receptor in gonadal tumors from inhibin $\alpha$-subunit knockout mice. Journal of Biological Chemistry 273 398-403.

Evans LW, Muttukrishna S, Knight PG \& Groome NP 1997 Development, validation and application of a two-site enzyme-linked immunosorbent assay for activin-AB. Journal of Endocrinology 153 221-230.
Fang J, Yin W, Smiley E, Wang SQ \& Bonadio J 1996 Molecular cloning of the mouse activin $\beta_{\mathrm{E}}$ subunit gene. Biochemical and Biophysical Research Communications 228 669-674.

Hötten G, Neidhardt H, Schneider C \& Pohl J 1995 Cloning of a new member of the TGF- $\beta$ family: a putative new activin $\beta_{C}$ chain. Biochemical and Biophysical Research Communications 206 608-613.

Imade GE, Baker HWG, de Kretser DM \& Hedger MP 1997 Immunosuppressive activities in the seminal plasma of infertile men: relationship to sperm antibodies and autoimmunity. Human Reproduction 12 256-262.

de Kretser DM, Foulds LM, Hancock M, McFarlane J, Goss N \& Jenkin G 1994 The isolation of activin from ovine amniotic fluid. Endocrinology 134 1231-1237.

Krummen LA, Woodruff TK, DeGuzman G, Cox ET, Baly DL, Mann E, Garg S, Wong W-L, Cossum P \& Mather JP 1993 Identification and characterization of binding proteins for inhibin and activin in human serum and follicular fluids. Endocrinology 132 431-443.

Laskov R \& Scharff MD 1970 Synthesis, assembly, and secretion of gamma globulin by mouse myeloma cells. I. Adaptation of the Merwin plasma cell tumor-11 to culture, cloning and characterization of gamma globulin subunits. Journal of Experimental Medicine 131 515-541.

McConnell DS, Wang Q, Sluss PM, Bolf N, Khoury RH, Schneyer AL, Midgley AR, Reame NE, Crowley WF \& Padmanabhan V 1998 A two-site chemiluminescent assay for activin-free follistatin reveals that most follistatin circulating in men and normal cycling women is in an activin-bound state. Journal of Clinical Endocrinology and Metabolism 83 851-858.

Martens JWM, de Winter JP, Timmerman MA, McLuskey A, van Schaik RHN, Themmen APN \& de Jong FH 1997 Inhibin interferes with activin signaling at the level of the activin receptor complex in Chinese hamster ovary cells. Endocrinology 138 2928-2936.

Mason AJ, Berkemeier LM, Schmelzer CH \& Schwall RH 1989 Activin B: precursor sequences, genomic structure and in vitro activities. Molecular Endocrinology 3 1352-1358.

Oda S, Nishimatsu S-I, Murakami K \& Ueno N 1995 Molecular cloning and functional analysis of a new activin $\beta$ subunit: a dorsal mesoderm-inducing activity in Xenopus. Biochemical and Biophysical Research Communications 210 581-588.

Pruett SB \& Lackey A 1987 Apparent interleukin 2 (IL-2) inhibitory activity of human serum is due to rapid killing of IL-2-dependent mouse cells. Clinical and Experimental Immunology 69 624-631.

Robertson DM, Foulds LM, Prisk M \& Hedger MP 1992 Inhibin/activin $\beta$-subunit monomer: isolation and characterization. Endocrinology 130 1680-1687.

Sakamoto Y, Shintani Y, Harada K, Abe M, Shitsukawa K \& Saito S 1996 Determination of free follistatin levels in sera of normal subjects and patients with various diseases. European Journal of Endocrinology 135 345-351.

Schwall RH \& Lai C 1991 Erythroid differentiation assays for activin. Methods in Enzymology 198 340-346.

Shao L, Frigon NL Jr, Sehy DW, Yu AL, Lofgren J, Schwall R \& Yu J 1992 Regulation of production of activin A in human marrow stromal cells and monocytes. Experimental Hematology 20 1235-1242.

Shimonaka M, Inouye S, Shimasaki S \& Ling N 1991 Follistatin binds to both activin and inhibin through the common beta-subunit. Endocrinology 128 3313-3315.

Uchimaru K, Motokura T, Takahashi S, Sakurai T, Asano S \& Yamashita T 1995 Bone marrow stromal cells produce and respond to activin A: interactions with basic fibroblast growth factor and platelet-derived growth factor. Experimental Hematology 23 613-618.

de Winter JP, Timmerman MA, Vanderstichele HMJ, Klaij IA, Grootenhuis AJ, Rommerts FFG \& de Jong FH 1992 Testicular 
Leydig cells in vitro secrete only inhibin $\alpha$-subunits, whereas Leydig cell tumors can secrete bioactive inhibin. Molecular and Cellular Endocrinology 83 105-115.

Woodruff TK, Sluss P, Wang E, Janssen I \& Mersol-Barg MS 1997 Activin A and follistatin are dynamically regulated during human pregnancy. Journal of Endocrinology 152 167-174.

Yamashita T, Takahashi S \& Ogata E 1992 Expression of activin A/erythroid differentiation factor in murine bone marrow stromal cells. Blood 79 304-307.

Ying S-Y, Becker A, Baird A, Ling N, Ueno N, Esch F \& Guillemin R 1986 Type beta transforming growth factor (TGF- $\beta$ ) is a potent stimulator of the basal secretion of follicle stimulating hormone (FSH) in pituitary monolayer system. Biochemical and Biophysical Research Communications 135 950-956.

Yu J, Shao L, Lemas V, Yu AL, Vaughan J, Rivier J \& Vale W 1987 Importance of FSH-releasing protein and inhibin in erythrodifferentiation. Nature 330 765-767.

Received 21 August 1998

Revised manuscript received 11 January 1999 Accepted 12 February 1999 